\title{
Community Nursing in Coastal Tourism through the Establishment of Coastal Health Center (POSKESPAN)
}

\author{
Komang Ayu Henny Achjar ${ }^{1}$, Moses Glorino Rumambo Pandin²* \\ ${ }^{1}$ Nursing Department, Health Polytechnic of Ministry of Health Denpasar, Indonesia \\ ${ }^{2}$ Faculty of Humanities, Universitas Airlangga, Surabaya, Indonesia \\ ${ }^{1}$ komangayuhenny@gmail.com; ${ }^{2}$ moses.glorino@fib.unair.ac.id
}

\begin{abstract}
Coastal tourist nursing is intended for coastal tourists related to the risk of accidents that may occur during the coastal activity. The risk of accidents in tourists can occur due to bad weather, lack of rescue equipment, and the limited ability of the coast guard to perform first aid and emergency treatment. This study described the relationship between coastal tourist nursing with the prevention of injuries and the first aid of coastal accidents, as well as the working procedures and obstacles that might occur during the rescue. The research was conducted by the qualitative method through in-depth interviews with respondents consisting of tourists, Balawista, and health workers. The data is analyzed with qualitative descriptive analysis. The interview generates 14 themes related to activities on coastal such as the duties of Balawista, warning signs, means of communication, improvement of ability, accident cases, accident treatment, referral of cases, needs of infrastructure facilities, human resources needs, health care needs, infrastructure factors, human factors, situation factors, and how to cope with the problem. Those themes can be used as a reflection in following up the safety service efforts to coastal tourists.
\end{abstract}

Keywords: Balawista; coastal tourist nursing; safety; tourist, POSKESPAN

\section{INTRODUCTION}

The characteristics of coastal tourism in Bali focus on natural beauty, free access for the public, mass tourism that involves the masses of people who visit popular tourist destinations. The characteristic of tourist in Bali was recorded very diverse (Tunjungsari, 2018), not all of the tourists have special expertise about nature, local tourists, and tourists with different cultures, accompanied by the density of people in a limited location, directly and indirectly, have special problems related to health and tourism. There were only a few articles described coastal tourism specifically about the important aspects of prevention related to the safety and satisfaction of the tourists.

Disclosure about mortality rate due to coastal activity in Bali was also dominated by drowning cases by $53.5 \%$ (Usaputro and Yulianti, 2014), thus improving the case fatality rate in Badung Regency by $3.2 \%$ from 2016 - 2017 based on a preliminary study 
to lifeguards in Kuta Beach. This condition cannot be compared with other coastal conditions due to the lack of data collection on the number of tourist visits on the coastal and the number of cases of other coastal accidents. This phenomenon reflects the weakness of efforts to prevent accident risks and to handle accident cases on the coast.

It was supported by the result of interviews conducted by researchers with the tourists in coastal, where $70 \%$ of data obtained said they did not know the existence of the coastal tourism rescue reinforcements (Balawista) as a team tasked with prevention and rescue on the coastal, the uniform used by Balawista and the warning prohibition signs on the coast still not socialized to tourists. The biggest accidents on the coast were caused by the behavior of people who do not know safety and do not comply with regulations according to safety standards. The results of a preliminary study conducted on the Balawista team on the coast of Badung regency, Bali Province, showed that the high number of accidents on the coast beside the proven characteristics of the waves that have the potential to cause high and extreme waves (Nurcahyo and Kisnarti, 2016). That cannot be controlled due to natural phenomena, so the anticipation efforts through early detection assessment of the ability of surfers need to be done to minimize the number of victims so that the assistance of novice surfers can be carried out.

The high number of accidents on the coast of Badung regency, Bali Province is also due to the negligence of tourists on warning signs on the coast, the lack of Balawista team compared to the number of tourists, limited sophisticated equipment, lack of ability to carry out rescue, and socialization of minimal accident risk prevention (Kusuma and Suryawan, 2016). So that, if the Balawista can explain about warning signs and tourist safety well, the accidents can be minimized.

The high number of accidents on the coast of Badung regency, Bali Province is also due to the negligence of tourists on warning signs on the coast, the lack of Balawista team compared to the number of tourists, limited sophisticated equipment, lack of ability to carry out rescue, and socialization of minimal accident risk prevention (Kusuma and Suryawan, 2016). So that, if the Balawista can explain about warning signs and tourist safety well, the accidents can be minimized.

The formation of coastal tourist nursing through the establishment of a coastal health center which engaged in providing services to tourists in the form of socialization related to the prevention of risk of injury and handling of cases of accidents on the coast 
carried out by trained Balawista. To realize the coast tourist nursing includes training of Balawista in theory and practice related to standard operational procedures for tourist safety. The aim of this training to improve the behavior of Balawista, safety, and tourist satisfaction on the coasts of Badung Regency, Bali Province. This study aims to provide an overview of coastal tourist nursing regarding the prevention of risk of injury and handling of accident cases on the coast, the need for carrying out safety tasks on the coastal, and the obstacles encountered regarding safety on the coastal.

\section{METHOD}

This research was conducted by a qualitative method by describing the statements from respondents based on their experiences. Respondents in this study involved tourists, Balawista, and health workers as many as 17 people based on the purposive sampling technique. The study was conducted on 8 coasts of Central Kuta District, Badung Regency, Bali Province by considering the high frequency of tourist visits, the existence of coastal rescuers, the high risk of coastal accidents even though the prevention has not been optimal. The technique of this research used in-depth interviews with the data sources were primary data and secondary data. Primary data sources were obtained from statements of tourists, Balawista, and health workers through the opened question, faceto-face interaction, and using unstructured interview guidelines.

Secondary data sources were based on the documentation and preliminary studies in the form of regulations and policies related to health in Badung Regency, regulations, and policies related to tourism in Badung Regency, Badung regional government policies, as a complement to the use of observation and interview methods. Data were analyzed using qualitative descriptive analysis techniques using a qualitative approach. The data analysis process begins with recording the results of interviews both through recorded and written records regarding the description of prevention of risk of injury on the coast, handling of accident cases on the coast, the need for carrying out safety duties for tourists, and the encountered obstacles regarding the safety of tourists on the coast. Processing interview data based on the keywords found to be sub-themes and finally getting the main theme or topic of the problem.

This research has also fulfilled the ethical requirements of research through the approval from the Ethics Committee of the Faculty of Nursing, University of Indonesia 
No. 0494/UN2.F12.D/HKP.02.04/2016, and research permission from the Kesbangpol of Badung Regency, Bali Province No. 070/726 / Kesbang on 13th July 2016.

\section{RESULTS}

The study conducted 17 participants consisted of 1) Six Balawista, 5 tourists, 6 health workers from Community Health Center in charge of the coastal. Entire participants have reached the data saturation. The characteristics of the participants were described in table 1.

Table 1. Characteristics of Participants $(n=17)$

\begin{tabular}{lccc}
\hline \multicolumn{1}{c}{ Characteristics } & Balawista & Health Worker & Tourist \\
\hline Gender & \multicolumn{3}{c}{} \\
Male & 6 & 3 & 1 \\
Female & - & 3 & 4 \\
Education & 2 & - & 4 \\
SHS & 4 & 6 & 1 \\
$>$ SHS & 251 years & $27-51$ years & $20-40$ years \\
Age & 6 & 6 & - \\
Length of work $\geq 3^{\text {th }}$ & - & - & 5 \\
Frequency of visits $>1^{\text {st }}$ time & $\mathbf{6}$ & \multicolumn{2}{c}{$\mathbf{6}$}
\end{tabular}

Based in table 1, the characteristics of the participants was dominated by male, the last educational status more than senior high school. The age range of participants was 20-51 years with work experience $\geq 3$ years. The frequency of tourist visits to the coast in Badung District was entire $>1^{\text {st }}$ visit.

The results of the theme explorations of 17 participants, to answer the prevention of injury risk on the coastal, handling of accident cases on the coastal, safety needs, and the obstacles. The triangulation results of the sources through interviews with 4 stakeholders (Head of Public Health Office, Head of Tourism Office, Head of Puskesmas I Kuta and Head of Puskesmas II Kuta) and 3 community leaders (Headman of Kuta, Legian, and Seminyak) were used to complement the data obtained from relevant participants related to the government policies and local regional policies.

This study resulted in 14 themes that were elaborated based on participant statements. The results of the theme exploration to answer the prevention of injury risk on the coastal described based on the theme of the task of Balawista on the coast, warning 
signs on the coastal, safety communication facilities on the coast, and increasing the ability of Balawista on the coastal.

The tasks of Balawista on the coast are to provide information, supervise, and putup safety signs on the coast. This statement supported by: "Routine patrols." (P1) "Provide information .." (P1, P2) "Supervise" (P1, P2) "put up the signs .." (P1, P2, P13,) "put up the flags ..." (P3, P12) "Inform the tourists ..." (P3, P13) "communicate .." (P3,) "keep monitoring .." (P12) "give directions ..." (P4) "gives an appeal ..." (P1, P4, ) "Put up the warning sign .." (P4,) "put up a bulletin board ... "(P4)

According to tourists and health workers, the duties of Balawista on the coast include providing directions, preventing accidents, and handling cases of accidents on the coast, such as the following data: "Provide directions" (P6) "provide information .." (P6, P7) “accident prevention." (P6) “handling cases" (P6) “safety" (P7, P8) “handling cases" (P6) "safety "(P7, P8, P11) "prevention of risk of injury .. "(P14, P16) "life-saver .... "(P11, P16) "first rescuer ... "(P17) "first treatment .. "(P14, P15) "Liaison of the victim to the hospital .." (P17, "rescuer of the coast ...." (P11, P16)

The theme that was also explored was that safety warning signs posted on the coastal were interpreted differently between Balawista and tourists. Balawista and health workers perceive the color and meaning of the flag according to the coastal safety rules, namely the red flag is not allowed to swim and the yellow flag is allowed to swim, such as the following data: "Red flags" (P1, P3, P4, P12, P13,) "red flags and yellow" (P1, P3, P4, P12) "red flags of danger"(P1)"red is not allowed to swim ... "(P3, P4, P12, P13) "red yellow is safe for swimming" (P1, P3, P4, P12,13).

It was different from the tourist statement that said yellow is dangerous, green is safe to swim, white is safe, black is safety prone, red is not too dangerous. The colors and meanings of the flag are inappropriate with the rules of safety on coastal, as the statement below: "Yellow flag...." (P7, P8) "green flag..." (P6) “black flag... "(P6) "white flag..." (P8) "dangerous yellow..." (P7, P8). "Green is safe swimming zone ..." (P6) "white is safe..." (P8) "black is safety prone ..." (P 6) "red is not too dangerous ..." (P6)

According to Balawista and tourists, the placement safety signs should be placed all over the coast line, coastal entrances, current pockets where coastal accidents often occur. The safety communication facilities used by Balawista were loudspeakers and whistles, such as the following participant statement: "Along the coast" (P1, P13) "every 
entrance" (P1, P4, P9) "every post" (P1, P3) "pocket of currents ..." (P1, P2) "people gather.." (P3) "dangerous areas..." (P6) "restricted areas..." (P6) "prone accident areas .." (P7) "every coast line..." (P13).

The theme of safety communication on the coast, explained by participants used loudspeakers, whistles, and direct information from Balawista, such as the following participant statements: “Loudspeakers...” (P1, P2, P3, P4, P7, P8, P9) “whistle...." (P1, P3, P4, P12, P13, P6, P7, P8, P9) “microphone...” (P3) “Talking...” (P9)

According to Balawista, the theme of improving the capacity of Balawista as a coastal rescuer team is supported by training is only carried out when the recruitment process becomes Balawista personnel, organized by Local Government of Badung and Balawista organizations with Australian Life-Saving trainers and senior Balawista. Refresher on the technique of handling coastal accident cases was carried out by Balawista every Friday at the Balawista's office. It was supported by the Balawista statement: "Trained first before becoming a Balawista ..." (P13) "meeting on every Friday for Balawistas ..." (P3, P12) "Local Government of Badung...." (P1, P2, P3) "Balawista organizations" (P1, P2, P3) "from organizations were charged a fee.... "(P1, P2, P3, P4, $\mathrm{P} 12, \mathrm{P} 13)$ "free of government fees...." (P1, P2, P3, P12) “we paid our own fees..." (P12, $\mathrm{P} 13)$ "from club organization, accidentally on vacation to Bali" (P3)

The training still used the old method of emergency assistance guidelines. The guidelines are based solely on the knowledge of the trainer, with training materials adapted to the frequent emergency cases on the coast of Badung Regency. "There is an old manual ..." (P3) "The book is only in the coach ..." (P4) "the old manual ..." (P3) "Help techniques on land and sea.." (P1, P4) "The techniques of bandage. ." (P2, P3, P12) "fracture..." (P2, P3, P12) “Cardiac pulmonary resuscitation...” (P1, P2, P4, P12) “stung by jellyfish... "(P2) “wound...”( (P2)

The results of theme exploration to answer the handling of accident cases on the coastal were described based on the theme of accident cases on the coastal, how to handle cases on the coastal, and case referrals. According to Balawista and tourist participants, cases of accidents on the coast include drowning, overheating, injury, and bleeding, jellyfish stings, which usually occur when the holidays. This was conveyed by Balawista participants as follows: “drowning....” (P1,P2,P4,P8,P9,P10,P13) "bleeding..(P1) “overheating.."(P1) “stung by jellyfish...”(P1)2) "the wound due to hitting the 
board...” (P4, P12, P13) “during the holidays...”(P1) “during school holidays....”(P2, P4) “holidays, new years, Eid Al-Fitr...."(P3)

Based on an interview with Balawista, the accident on coastal often occurred due to the lack of understanding, lack of information, lack of discipline by tourists, the ability to swim by tourists, and crowded visitors. According to tourists because they do not know the existence of Balawista and safety signs on the cost, they neglected self-safety during the travels, such as the following statement: "Do not understand signs" (P2, P10, P13) "lack of information.." (P2, P4) "lack of discipline" (P1, P2, P8, P9, P12) "lack of swimming ability" (P4, P13) "when the visitors is dense..." (P1)“ do not know the existence of Balawista..." (P9, P10)

Refers to the interview, another theme is about the handling of accident cases on coastal through evacuation, resuscitation as first aid efforts on coastal accidents, and case referrals. As the statement from Balawista follows: "Evacuate .." (P1, P2, P4) "refer to the hospital .." (P1, P3) "Cardio Pulmonary Resuscitation" (P1, P2, P3, P4) "artificial respiration ..." (P2, P3, P4, P9, P12, P13)

The theme of referral of coastal accident cases usually directed to government hospitals and international hospitals on the grounds of proximity to the coastal, international standard and according to victim insurance, so far they have never made a case referral to Community Health Center as a health facility that covers the coastal area due to the lack of medical equipment and the unresponsive medical treatment. According to Balawista, cases of coastal accidents that have been referred to the hospital are not subject to further monitoring. This can be seen from the following participant statements: "referred to international hospitals (P1, P2, P3, P4, P12, P13, P11, P14, P15, P16) "never been to the community health center (P4, P13, P5, P11)" Sanglah Hospital ... "(P1, P13, P14) "closest ... " (P1, P2, P3, P5, P11, P12). “The medical equipment in community health center not too complete ... (P1) "insurance ..." (P1, P2, P13). "International level ... (P4, $\mathrm{P} 17, \mathrm{P} 14, \mathrm{P} 16)$ is not very alert" (P1) "there is no more monitoring" (P3, P12)

The results of the theme exploration to answer the need for infrastructure needed on the coastal were explained through the themes of the need for infrastructure, human resource needs, and health service needs on the coast.

Related to the statement from Balawista, the theme of the infrastructure needed on the coastal requires an increase in the number of guard centers on the coastal, there is 
a need for guidelines for handling accident cases on the coastal, there is a need for safety leaflets and the addition of medicines. According to tourists, there is a need for buoys and oxygen when handling accident cases on the coast. According to the three participants, the most needed need is medicine on the coastal, as stated by the following participants: "First aid box with the medicine" (P1, P2, P3, P4, P6, P7, P8, P9, P10, P12, P13, P14, P15). "Add more guard centers" (P1, P2, P3) "buoys" (P6, P7, P8, P9, P10) "oxygen" (P8, P10) "handling guidelines" (P2) "Leaflets / flipcharts / posters" (P8, P13) "safety tools" (P1, P2, P9)

The next theme is the need for human resources on the coast. Concludes the statement from Balawista, to assign health workers in coastal, professional health workers are required. According to Balawista, a nurse is needed in an ambulance and additional Balawista on the coastal, as stated by the following participants, "Nurses in ambulances" (P1, P2, P3, P4, P13) “additional Balawistas .." (P1, P7) "health workers on the coastal...” (P1, P5, P7, P9, P11, P14, P15, P16, P17)

The theme of the need for health services on the coastal. According to all participants, it is necessary to have health services on the coast to optimize tourism services, cross-sectoral cooperation is needed to make the service more professional. The reason for the need for health services on the coastal based on the statement from Balawista is due to the lack of capacity of Balawista in handling cases and for better treatment with health workers on the coastal. According to tourists, so that it can be handled more quickly and minimize the death of victims. It was explained in the following participant statement: "Need health services on the coast ..." (P1, P2, P3, P4, P6, P7, P8, P9, P10, P12, P13) "need cross-sectoral cooperation" (P2, P5, P8, P11, P14, P15, P16, P17) "optimizing tourism services ... (P4, P5, P6, P11)" lack of skill of Balawista.. "(P3)" more professional "(P4, P5, P6, P7, P11, P14, P15, P16, P17) “Minimize mortality...” (P6) “handle it faster...” ((P6, P7, P8, P9, P10)

The results of the theme exploration to answer the obstacles encountered regarding the safety of tourists on the coastal were answered through the themes of infrastructure factors, human factors, environmental factors, and how to cope with the problems.

The theme of obstacles is in terms of safety infrastructure facilities on the coast, according to Balawista the supply of medicines, safety equipment on the coastal, the 
number of guard centers is not sufficient and needs additional. This was explained as follows: "Inadequate medicine" (P1, P2, P3, P4, P13) "equipment is still minimal ..." (P1, P2, P3, P4) "guard centers are lacking ..." (P1, P2)

The theme of obstacles in terms of human factors explained according to health workers, the obstacles due to the lack of human resources with basic cardiac life support certification that can be placed on the coastal, the limited number of health workers at the community health center, the lack of ability of Balawista to speak English and the referrals that are deemed lacking integrated. This was explained by the participants as follows: "Lack of BHD certified human resources.." (P17) "The lack of professional Balawista..." (P5, P11,14, P15, P17) "difficult to speak English ..." (P14, P15, P16, P17)

Based on Balawista, the obstacles on human resources in terms of comparison of Balawista and tourists are still lacking, such as the statement from Balawista below: "Lack of Balawista..." (P1, P2, P13) "the crowded tourist..." (P1, P3)

The theme of the obstacles encountered was related to situational factors and how to solve the problem, explained according to Balawista participants and tourists because of the waves and traffic jams, such as the following statement: "Big waves ..." (P2, P3, P6, P12) "road jammed ..." (P17)

Another theme is how to cope with the obstacles, explained by Balawista participants and tourists by making proposals to international hospitals for the request of medicine, providing safety information to tourists, adding personnel, making referrals of victims to the nearest hospital. Supported by the following statement: "Proposals to international hospitals (P2, P3, P4, P12)" "refer directly to the nearest hospital ... "(P1) " need information ... "(P2, P7, P8,)" additional personnel ... (P1)

Based on the results of interviews with the Regional Headman, it was explained that "the number of health workers in the health center is limited" "the supply of medicines were limited from the tourism office", "there is no cross-sectoral cooperation", "training is not routine" "needs trained health personnel" "coastal safety brochure" "not yet referred to the community nursing center", "there is no record of reporting of coastal accidents". 


\section{DISCUSSION}

Community nurses need to build a partnership with the community and cooperate with the community, therefore community nurses need to provide encouragement or empowerment to the community in order to create active participation from the community (Yu et al., 2014). Building public health is inseparable from efforts to increase capacity, leadership, and community participation (Nies and McEwen, 2015). Partnerships were conducted by community nurses through efforts to build and foster the networks up with relevant parties in efforts to address both family, group, and community levels. Therefore, building partnerships should be based on the terms of partnership which are equal attention, mutual trust, mutual awareness of the meaning of partnership and equality of vision, mission, goals, and values equally, understanding each other's positions, tasks, functions, and abilities, contacting and approaching each other, being open and helpful to each other, encouraging and appreciating each other and the principles of partnership, in the form of equality, openness, and mutual benefit.

Priority targets for nursing services in the community carried out in vulnerable or high-risk communities due to health problems, communities with difficult geographical conditions such as remote areas, disaster-induced communities or others, communities with higher rates of health due to morbidity or mortality rates than other areas, or communities with low health care coverage (Stanhope and Lancaster, 2016). One of the community nursing activities in a particular setting that community nurses do in interacting with tourists on the coast, becomes the realm of community health nursing in a particular area on the coast, in the risky population of both individuals, groups, and communities.

Community health nursing strategies include group processes, health education, empowerment, and partnerships (Stanhope and Lancaster, 2016). The community health nursing strategy aims to increase community participation in solving health problems. Based on a statement from Pender et al., (2011), every group process that occurs in the community aims to raise self-sensitivity, elicit solidarity, and mutual respect through existing social support systems.

Health education can be effective when it can make an improvement in knowledge, attitudes, skills, and even influence changes in the behavior or lifestyle of individuals, families, and groups (Pender et al., 2011). Community capacity is an effort 
to improve the ability of individuals, organizations, and communities to develop existing potentials, skills, resources, and geographic excellence by reconsidering the strengths and opportunities of community capabilities in development (Suarez-Balcazar et al., 2008). For this reason, community capacity building is an activity to develop potential, skills, community resources in accordance with the capabilities of the community.

\section{Community Capacity}

Community capacity in the context of tourism includes organizations, communities, and individuals (Flaspohler, 2008). Community capacity is the capacity of people in the community to participate in tourism activities (Aref and Redzuan, 2009). Community capacity moving parallel with community development, community capacity building is very important in tourism development. Moscardo (2008) explained community capacity building is necessary for community development and participatory processes at the community level. The capacity of the community in tourism development can be seen as the capacity of people in the community to participate in tourism activities (Cupples, 2005). Fiona (2007) stated that community capacity building is an important factor in strengthening the welfare of individuals and local communities, with the support of local authorities. Community capacity building is the ability to empower citizens to manage themselves.

Based on the results of Salanguit (2009), conducted in Naga City, Philippines shows that community capacity building can be done by engaging the potential of local communities through improved skills and access to information. Involving the role of Balawista in maintaining the safety in coastal also can cultivate confidence in themselves to engage tourists more aware with the threat of disaster in coastal areas. Increased confidence in self-ability is also felt in students after being directly involved in the implementation of disaster management in the field (Hindriyastuti et al., 2019).

Community capacity at the organizational level requires the role of professionals to help provide services in community development (Aref and Redzuan, 2009). Community capacity can be done with local development partnerships by local governments, private parties, and other public sources. According to Nies and McEwen (2015), community health development as an approach in community organizing combines concepts, objectives, and processes of public health and community development. 
Community nurses in public health development are identifying community needs related to health and then developing, approaching, and evaluating health development goals through partnerships with other related professions. Therefore, knowing the characteristics of the community is a requirement to gain public acceptance of health services and improve health services in a particular communities.

\section{Prevention}

Precautions consist of three measures in accordance with the expected objectives and results. Primary prevention is used to prevent the risk of injury, injury, and disability of individuals and groups susceptible to health problems, in the form of environmental protection health promotion (Lancaster and Stanhope, 2014)(J. . Allender, Rector and Warner, 2014).

Secondary prevention is to provide immediate care measures by conducting health referrals to victims of coastal accidents, conducting health screenings with early detection of health disorders such as vital sign measurements of coastal communities, detection related to the possibility of minimizing coastal safety risks, minimal service before health referral. Aim to prevent more damaging effects, by early diagnosis and prompt treatment such as health screening, early detection of health disorders (Stanhope and Lancaster, 2016)(Anderson and Mc Farlane, 2011)(Nies and McEwen, 2015).

Tertiary prevention is a collaboration in the handling of coastal accident cases against all communities around the coast, collaboration with other health workers in an effort to facilitate incompetence and prevent mortality. Tertiary precautions prioritize the prevention of complications as well as minimizing disability limitation and maximizing function through rehabilitation, facilitating disability and preventing death (J. A. Allender et al., 2014) (Stanhope and Lancaster, 2010)(Anderson and Mc Farlane, 2011)(Nies and McEwen, 2015).

\section{Empowerment}

Empowerment is a process of developing knowledge and skills to improve people's abilities (Anderson and Mc Farlane, 2011). Empowerment is also a process that allows people to choose, control, and make decisions about their lives, with mutual respect for 
everyone (Friedman, Bowden and Jones, 2002). Community empowerment will ultimately result in community self-reliance.

Lertputtarak (2012) stated that community participation in the planning and development of tourism development is indispensable from a sustainable tourism perspective. On the ground of this, engaging the community for developing the tourism can add a value to national tourism.

\section{The Role of Community Nurses}

Nurses in the nursing coastal tourism community can conduct health education related to the use of safety signs, the use of safety tools, safe limits of the swim, the spread of safety leaflets, early detection of vital sign measurements on coastal communities, handling cases of accidents on the coast before victims are referred to the health service. Community nurses should be able to use the resources in the community and help the community make decisions to maintain and improve their health (J. A. Allender et al., 2014). Nurses can act as defenders/advocates in helping the community overcome the problem (Ben-Natan, Ben-Sefer and Ehrenfeld, 2009). Community nurses can review and identify clients' health needs, design nursing plans to meet clients' needs, supervise and evaluate the impact on services provided (J. A. Allender et al., 2014) (Nies and McEwen, 2015). Nurses in the nursing coastal tourism community can conduct activities as case managers, ranging from planning by helping to identify resources in the coastal community, motivating and coordinating in meeting the needs of community health services on coastal tourism, organizing all accident prevention and handling activities, supervising all service activities on the coast.

Community nurses with a variety of research activities, applying research results and nursing practices, collecting data, designing, and disseminating research results are used to identify the nursing interventions (Kulbok and Ervin, 2012). Nurses as liaisons assist in maintaining continuity between professional and non-professional officers. Community nurses are expected to refer client issues to health care facilities as well as resources in the community such as health centers, hospitals, religious leaders, community leaders (Allender and Spradley, 2012). Nurses in coastal tourism nursing can act as a liaison to other referral health services, to other health professionals related to the problems experienced by coastal communities. Community nurses also become a 
facilitators in assisting Balawista in conducting hazard management process on the coast. The role of nurses as facilitators based on Susilaningsih, Dayfi and Yudianto (2018) on this study is applied in the rescue of beach tourists in the form of facilitating the latest information and rescue facilities that can be applied in the rescue process.

Tourism generally has a socio-cultural impact on people and tourist destinations, such as changes in people's livelihoods with changes in work adapting to the needs of tourists, changes in cultural aspects of both language, tradition, and the transformation of norms and values. In addition to changing demographic aspects with an increase in the number of residents around the tourist area also changes the environmental aspects around tourist attractions such as traffic congestion, pollution (Sedarmayanti, 2014).

Coastal in Bali is a natural and cultural tourist attraction that has an attraction because of the special value of art and traditional ceremonies. Tourist attractions are all that are targeted by tourism. Attractions can be grouped into (Unga, 2011).

Duties of Coast Guard. Balawista is a supporting element for quality of coastal tourism destinations for tourists who use all coast facilities, planning is important before making a tour related to the length of stay and the cost required during the tour visit (Crosskill, 2018). Balawista has daily tasks such as observing the weather conditions and the situation of the water area, determining and signaling the safety situation for coastal visitors, banning or allowing tourists to do activities in the water area, providing assistance to tourists who have experienced accidents on the coast (Dewi, 2009) take precautions and handling victims, provide information on safe swimming areas, conduct surveillance and urges, it is required to provide a sense of security and comfort of tourists to help the promotion of tourism towards the level of tourist visits (Wardhani, 2018).

Tourist. Tourists are all people who travel intending to gain pleasure, not to work, to settle, and to make a living (Irawan, 2010). Characteristics of tourists who tour on the coast include in mass tourism, tourists usually come to famous and popular tourist destinations, involving masses of people (Weaver, 2012). Mass travel often involves package holiday deals such as visiting theme parks, sunbathing on popular coast.

Tourism Safety. Safety concerns efforts to develop programs to prevent injuries, improve public safety, conduct partnerships between governments, non-governmental, community organizations, and individuals (Davis, 2014). Thus, public safety is an activity 
related to crime reduction and prevention efforts through improved services and partnerships. Public safety is the responsibility of all parties includes governments, other community institutions, organizations and associations, and also communities (Gondek \& Tabaczniuk, 2011).

Causes of Accidents. Based on the results of research from Khosravi et al., (2014), the biggest cause of accidents is due to unsafety behavior and unsafe environmental conditions. Unsafety public behavior such as disobeying regulations, being less cautious, not following existing safety procedure standards, not using unqualified safety tools, environments or equipment, natural factors (Khosravi et al., 2014). The high mortality and disability rates are also affected by the severity of accidents experienced by victims, the lack of knowledge and attitude of health workers towards the handling of accident emergency patients, and the lack of equipment available.

Characteristics of Balawista. Nurhanifah (2015) explained that older officers show low-quality treatment in handling patients, productivity decreases in line with a person's age. A higher level of education can make it easier for a person to absorb the information he or she receives and be able to implement it in real behavior. Formal education shapes a person's value especially in receiving new materials (Yacoub, Miranti and Herkulana, 2016). Work experience can increase new information and insights. A person with a long working life tends to adapt to the work environment so that it can affect comfort in work (Saragih, Rosita and Rumapea, 2011).

\section{CONCLUSION}

Identified descriptions related to injury risk prevention, handling of incidents of accidents on the coast, safety needs and safety barriers encountered on the coast into 14 themes described based on the participant's statement, namely the theme of Balawista duty on the coast, warning signs on the coast, means of safety communication on the coast, improvement of Balawista capabilities on the coast, cases of accidents on the coast, how to handle cases on the coast, case referrals, needs for infrastructure facilities, human 
resources needs, health care needs on the coast, infrastructure factors, human factors, situation factors and how to solve problems.

The model of nursing coastal tourist through POSKESPAN is one of the service activities provided for tourists visiting the coast related to the prevention of the risk of injury and the handling of accidents on the coast. This model is suitable for coast tourism in Bali, because of the high health risks of tourists when visiting coast tourism, the high number of tourist visits especially during vacation, tourists with different cultures and characters, tourists focus only on natural beauty without thinking about the health risks encountered when doing coast tourism, tourist activities in coast tourism to sunbathing, swimming and surfing without specific skills about nature.

The model of nursing coastal tourists through POSKESPAN requires the involvement of Balawista as a coastal rescuer team, with the involvement of a team of Community Health Center nurses and related stakeholders include local government, Tourism Office, Health Office, community leaders, and other coastal communities. The role of Balawista and Community Health Center nursing team in the nursing model of coastal tourists through this POSKESPAN, is expected to help tourists conducting safe coast tourism activities, and tourists feel satisfied to enjoy coast tourism in Bali.

\section{RECOMENDATION}

There needs to be dissemination to the health sector and tourism sector towards the existence of the coastal tourist nursing model (KWP) through POSKESPAN as another alternative to community-sourced health efforts in Indonesia. POSKESPAN is more towards handling the emergency outside the building, targeting coastal communities in a particular order of the coast, placing the nursing team of Community Health Center as the manager of the POSKESPAN for primary and secondary prevention while guiding Balawista activities as a cadre of POSKESPAN, cross-sector partnerships, involving local governments. 


\section{REFERENCES}

Allender, J. ., Rector and Warner (2014) Community \& Public Health Care. Lippincott Williams \& Wilkins.

Allender, J. . and Spradley, B. . (2012) Community health and nursing, concept and practice. California: Lippincott Williams \& Wilkins.

Allender, J. A., Rector, C. and Warner, K. (2014) Community \& Public Health Nursing: Promoting and Protecting the Public's Health. 8th edn. Philadelphia: Lippincott Williams \& Wilkins.

Anderson, E. . and Mc Farlane, J. . (2011) Community as Parthner, theory \& Practice in Nursing. 6th edn. Philadelphia: Lippincott Williams \& Wilkins.

Aref, F. and Redzuan, M. B. (2009) 'Community capacity building for tourism development', Journal of Human Ecology, 27(1), pp. 21-25. doi: https://doi.org/10.1080/09709274.2009.11906187.

Ben-Natan, M., Ben-Sefer, E. and Ehrenfeld, M. (2009) 'Medical tourism: A new role for nursing?', Online Journal of Issues in Nursing, 14(3), pp. 1-9. doi: 10.3912/OJIN.Vol14No03PPT02.

Crosskill, N. (2018) Mengenal Profesi Baywatch. Available at: www.tribunnews.com (Accessed: 11 March 2019).

Cupples, J. (2005) What is community capacity building? Available at: https://www.ccwa.org.uk/v2/downloads/cms/1121303664 (Accessed: 11 March 2019).

Dewi, A. C. (2009) Pusat Balawista Di Kabupaten Badung, Provinsi Bali. Universitas Diponegoro. Available at: http://eprints.undip.ac.id/1527/.

Fiona, V. (2007) Community Capacity Building- A Review of The Literature. Available at: $\quad$ http://www.health.sa.gov.au/PEHS/branches/health-promotion/0711capacity-building-review-lit.pdf (Accessed: 10 March 2019).

IFlaspohler, P. (2008) 'Unpacking prevention capacity: An intersection of research-topractice models and community-centered models"', American Journal of Community Psychology, 41(3-4), pp. 182-196.

Friedman, M. R., Bowden, V. R. and Jones, E. (2002) Family Nursing: Research, Theory, and Practice. 5th edn. New Jersey: Pearson.

Hindriyastuti, S. et al. (2019) 'Nursing Students' Roles and Experiences of Disasters in A Nursing School', Jurnal Keperawatan Padjadjaran, 7(1). doi: 10.24198/jkp.v7i1.997.

Irawan, K. (2010) Potensi Objek Wisata Air Terjun Serdang Sebagai Daya Tarik Wisata Di Kabupaten Labuhan Batu Utara. Universitas Sumatera Utara.

Khosravi, Y. et al. (2014) 'Factors influencing unsafe behaviors and accidents on construction sites: A review', International Journal of Occupational Safety and Ergonomics, 20(1), pp. 111-125. doi: 10.1080/10803548.2014.11077023.

Kulbok, P. . and Ervin, N. . (2012) Nursing Science and Public Health, Contributing to The Discipline of Nursing. Nursing Science.

Kusuma, S. W. and Suryawan, I. B. (2016) 'Penerapan Keselamatan Dan Kesehatan Kerja Balawista Di Pantai Kuta', Jurnal Destinasi Pariwisata, 4(1), p. 31. doi: 10.24843/jdepar.2016.v04.i01.p06.

Lancaster, J. and Stanhope, M. (2014) Public Health Nursing Population Centered Health Care in the Community. 8th edn. St. Louise: Mosby.

Lertputtarak, S. (2012) 'The Relationship between Destination Image, Food Image, and Revisiting Pattaya, Thailand', International Journal of Business and 
Management, 7(5), pp. 111-122. doi: 10.5539/ijbm.v7n5p111.

Moscardo, G. (2008) Building Community Capacity for Tourism Development. Cambridge, Australia: CABI.

Nies, M. and McEwen, M. (2015) Community/Public Health Nursing: Promoting The Health of Populations. 6th edn. St. Louise: Elsevier/Saunders. Available at: https://www.elsevier.com/books/community-public-health-nursing/nies/978-0323-18819-7.

Nurcahyo, M. A. and Kisnarti, E. (2016) Analisis Karakteristik Tinggi Gelombang Ekstrem dan Nilai Transfomrasi Gelombang Pantai Kuta Bali Muhamad Adi Nurcahyo, Engki A. Kisnarti, Universitas Hang Tuah. Surabaya: Perpustakkan Ilmu Sosial dan Ilmu Politik.

Nurhanifah, D. (2015) Hubungan Karakteristik, Beban Kerja Dan Supervisi Dengan Motivasi Perawat Dalam Melaksanakan Triase Di Instalasi Gawat Darurat RSUD Banjarmasin. Universitas Muhammadiah Banjarmasin. Available at: http://journal/ac.id/index.php/caring/article/view/24.

Pender, N. J., Murdaugh, C. L. and Parsons, M. A. (2011) Health Promotion in Nursing Practice. 6th edn. Upper Saddle River: Pearson.

Salanguit, P. A. K. (2009) 'Community Capacity Building and Local Government Leadership: Describing Transformational Leadership Practices in Naga City, the Philippines', Ethnicity \& disease, pp. 18-41. doi: https://ci.nii.ac.jp/lognavi?name=crossref\&id=info:doi/10.34382/00011599.

Saragih, Rosita and Rumapea, N. (2011) 'Hubungan Karakteristik Perawat Dengan Tingkat Kepatuhan Perawat Melakukan Cuci Tangan di Rumah Sakit Colombua Asia Medan', Jurnal Ilmu Keperawatan, 3(1).

Sedarmayanti (2014) Membangun dan Mengembangkan Kebudayaan dan Industri Pariwisata. Bandung: PT. Refika Aditama.

Stanhope and Lancaster (2010) Foundations of Nursing In The Community, communityoriented practice. 2nd edn. St. Louise: Mosby Elsevier.

Stanhope, M. and Lancaster, J. (2016) Public Health Nursing Population Centered Health Care in The Community. 8th edn. St. Louise: Mosby.

Suarez-Balcazar, Y. et al. (2008) 'Capacity Building and Empowerment: A panacea and a challenge for agency-university engagement', Gateways: International Journal of Community Research and Engagement, 1(November 2015), pp. 179-196. doi: 10.5130/ijcre.v1i0.626.

Susilaningsih, F. S., Dayfi, B. A. and Yudianto, K. (2018) 'Implementation of Roles and Functions of Case Managers', Jurnal Keperawatan Padjadjaran, 6(3), pp. 253263. doi: 10.24198/jkp.v6i3.403.

Tunjungsari, K. R. (2018) 'Karakteristik dan Persepsi Wisatawan Mancanegara di Kawasan Sanur dan Canggu, Bali', Jurnal Pariwisata Terapan, 2(2), p. 108. doi: 10.22146/jpt.43178.

Unga, K. L. O. (2011) Strategi Pengembangan Kawasan Wisata Kepulauan Banda. Universitas Hasanuddin.

Usaputro, R. and Yulianti, K. (2014) 'Tenggelam Berdasarkan Data Bagian Ilmu Kedokteran Forensik Rumah Sakit Umum Pusat Characteristic and Risk Factors Death Caused By Drowning According To Forensic Medicine Section of Sanglah Hospital From 2010 To 2012', E-jurnal Medika Udayana, 3(5), pp. 551-561. doi: 10.24922/eum.

Wardhani, A. . (2018) Kisah Lifeguard. Available at: tribunnews.com (Accessed: 18 
March 2019).

Weaver, D. B. (2012) 'Organic, incremental and induced paths to sustainable mass tourism convergence', Tourism Management. Elsevier Ltd, 33(5), pp. 1030-1037. doi: 10.1016/j.tourman.2011.08.011.

Yacoub, Y., Miranti, E. and Herkulana (2016) 'Pengaruh Tingkat Pendidikan, Masa Kerja Dan Motivasi Kerja Terhadap Kinerja Karyawan Erien Miranti, Herkulana, Yarlina Yacoub', Jurnal Pendidikan dan Pembelajaran, 5(3), pp. 1-13.

Yu, D. et al. (2014) 'Assessing Urban Public Safety via Indicator-Based Evaluating Method: A Systemic View of Shanghai', Social Indicators Research, 117(1), pp. 89-104. doi: 10.1007/s11205-013-0366-z. 